\title{
Free autologous fat in spine surgery to prevent adhesion, cicatrisation, and cerebrospinal leakage. Assessment of the practical side of this method
}

\section{Zastosowanie wolnego autogennego płata tłuszczowego w zapobieganiu bliznowaceniu i uszczelnianiu płynotoku. Praktyczna ocena metody}

\author{
Jarosław Andrychowski¹, Farag Abaaslam² \\ ${ }^{1}$ Collegium Medicum, University Jan Kochanowski, Kielce, Poland \\ Head of the Collegium: Prof. Marianna Janion MD, PhD \\ 2Department of Neurosurgery, Faculty of Medicine (Al-Marj), University of Benghazi, Benghazi, Libya \\ Head of the Department: Dr. Mohamed Ali
}

Medical Studies/Studia Medyczne 2020; 36 (3): 224-229

DOI: https://doi.org/10.5114/ms.2020.99548

Key words: free fat transplant, scar tissue, spine surgery, scar prevention.

Słowa kluczowe: wolny przeszczep, bliznowacenie, chirurgia kręgosłupa, przeciwdziałanie bliźnie.

\begin{abstract}
Autogenic free fat tissue (FFT) is widely used in neurosurgery. Since the 1960s, there has been discussion on the usefulness of fat graft in spinal surgery. Unfortunately, fat undergoes atrophy, fibrosis, and rebuild, and up to $55 \%$ of primary volume disappears. This review focuses on the following aspects: development of radiological assessment, evaluation of morphological changes, and the influence of fat graft on outcome. Fat graft in the spinal canal disappears after degeneration processes. High amounts of collagen in the studied tissue and proliferation of blood vessels were observed. Use of fat as a filler and dural sac sealer is well grounded; however, the prevention of scar formation is uncertain. The use of fat does not eliminate adhesion and scar formation near the dural sac. Meanwhile, as the results of the discussed studies show, routine use of fat graft in prevention of scar formation cannot be justified.
\end{abstract}

\section{Streszczenie}

Autogenny przeszczep tkanki tłuszczowej (FFT) jest szeroko stosowany w neurochirurgii. Od lat 60. ubiegłego wieku toczy się dyskusja dotycząca przydatności przeszczepu płata tłuszczowego w chirurgii kręgosłupa. Obserwacje wskazują, że przeszczep ulega atrofii, włóknieniu oraz przebudowie, zanik objętości graftu może wynosić nawet do $55 \%$. W analizie skupiono się na metodyce oceny radiologicznej, ocenie morfologii przeszczepu oraz możliwym wpływie leczenia w chorobie degeneracyjnej kręgosłupa na efekt kliniczny. Stwierdzono, że graft tkanki tłuszczowej zanika i degeneruje, pojawia się także włóknienie i proliferacja naczyń w obrębie przeszczepu. Zastosowanie FFT w postaci tkanki wypełniającej defekty kosmetyczne lub uszczelniacza worka oponowego w płynotoku jest ugruntowane, natomiast jego rola w zapobieganiu bliznowaceniu jest niepewna. Nie istnieje zalecenie dotyczące stosowania graftu tkanki tłuszczowej jako rutynowego postępowania w zapobieganiu bliznowaceniu w chirurgii kręgosłupa.

\section{Introduction}

Free fat tissue (FFT) graft is used as an isolation, filler, and sealing agent. Its use if often intuitive, based on the experience of a surgeon, and it is not associated with knowledge of FFT properties. In the surgery of the spinal canal FFT is used in case of liquorrhoea and as an isolating agent. Based on the presence of fat tissue in the epidural space in normal anatomical situations, it was suggested that fat graft be used to prevent scar formation after a neurosurgical spine approach. The process of scar formation in the spinal canal observed following degenerative spine surgeries is an undesirable event and may be a reason for a failed post-operative course; moreover, it complicates reoperation cases.

Minimally invasive spine surgery (MISS) methods are used to prevent undesirable scar formation in the spinal canal. Only surgeries of spinal fixation and osteosynthesis are associated with a larger exposure of a surgical field.

However, the use of fat graft in spinal procedures and a larger coverage of a surgical field are not final 
solutions to the problem of avoiding scar formation, due to autogenous material properties. Many studies have been performed looking for heterogeneous materials to be used as membranes or anti-scar gels replacing the FFT graft. High hopes are associated with the use of biologically neutral, biodegradable membranes obtained with nanotechnology to eliminate foreign body reaction. Surgeons' opinions regarding the use of FFT in spinal surgery are ambiguous as a result of a lack of reliable analysis of long-term results of using autologous fat tissue.

Plastic surgeons received interesting results when using a fat flap as an autogenous filling cosmetic agent. Due to the loss of a primary volume of implanted fat tissue reaching up to $55 \%$, the expected cosmetic effects can disappear after a year. Additional undesirable effects included local fibrosis and histological remodelling that changes the parameters of plastic reconstruction.

Clinical observation of FFT morphological features in the field of spinal canal surgery was not possible, and imaging research techniques were necessary. Before the computed tomography (CT) and magnetic resonance imaging (MRI) era, radiological examination did not exist. Only a few cases that were verified during reoperations were subject to a histopathological assessment of the implanted fat tissue. Few samples obtained during reoperation provided information regarding fibrosis and morphological changes in fat graft. A postoperative clinical assessment of surgical management performed after many months in an outpatient setting is a tool to verify scar prevention in clinical practice and outcome. Additional analysis of undesirable treatment effects associated with FFT compressing the spinal cord or the cauda equina structures is also important.

\section{History and review}

Free fat flap has been used for a long time in different methods of surgical management. It was used for the first time during orbital cavity reconstruction in 1893 (Neuber). In the early 1920s reconstruction of facial hemiatrophy was performed using a fat flap. The possibility of using fat tissue was discovered by Erich Lexer in 1919 [1]. Hilse A and Rehn E also noticed that fat tissue can be used in different aspects of surgery [2, 3]. In 1920 Eitner used fat flap during a plastic surgery of a cheek [4], and in 1931 Figi used FFT to correct an invagination in the frontal sinus area [5].

The moment when fat flap was used for the first time in spinal surgery cannot be precisely determined, but it can be suspected that it is associated with publications regarding scar formation from the 1960s. Subsequent publications in this field were published at the beginning of the 1970s and 1980s.

A management strategy with FTT was suggested for the first time in the medical publication by authors from Finland, in a preliminary report from 1976 [6]. The authors studied prevention of scar formation using FFT based on an experimental model. This paper was innovatory at that time, but currently, some defects associated with unreliable figures and overly short duration of observation of scar formation are obvious. However, the results of experiments were thought to be optimistic.

In their subsequent publications the authors suggested a management strategy in human centres [7]. In 1985, after more than 10 years of using this method, a paper presenting results of a morphological assessment of fat tissue flaps was published by Langenskiöld et al. [8]. Imaging tests (CT scan) indicated that the fat graft was visible at the place it was applied. Transplanted fat was compared to other areas of fat tissue, and according to the authors the parameters and morphology of the implanted material were maintained. There were the following obstacles: an extremely low number of examined patients (i.e. four), lack of possibility to assess the extent of atrophy of the FFT that was initially placed, and lack of a histological assessment.

In 1980 Mayfield presented results of 16-year experiments on the use of FFT as a sealing agent for the dura mater sac in cases of liquorrhoea and regarding management to prevent scar formation inside the spinal canal [9]. In this period only a few scientific reports were dedicated to the subject of monitoring the shape and morphology of FFT. The paper published by Bryant et al. (1983) is of note because they analysed epidural FFT placement during surgeries of degenerative spine in a group of 44 patients. Clinical and radiological assessments were made using CT scan. In more than $60 \%$ of examined patients, signs of FFT survival were observed, but the volume of an introduced flap decreased by half. In several cases after the introduction of FFT a serous exudate the seroma was observed in the epidural space. No infection occurred in situ of the postoperative wound. The authors drew attention to the possibility of so-called dead space associated with skin sutures. The foreign body reaction to avascular fat flap was not observed, so the method was recommended for routine management [10]. In many publications relatively low numbers of patients subjected to analyses were obstacles against a reliable assessment. In the paper by Van Akkerveeken et al. from 1986 [11], 26 patients treated for degenerative spine were examined within a 2 -year period. Complete monitoring of the fat graft dimensions was performed in $80 \%$ of patients in the examined group. In $50 \%$ of cases a CT scan revealed that the shape of introduced FFT had not changed after 2 years. In several cases changes typical of fibrosis, as well as FFT atrophy, were observed. The publication emphasises the relationship between the width of a fat tissue flap, the dimensions of a preparation, and exposure of a surgical field with vascularity and conditions of graft survival. 
Vascularity and survival of FFT were confirmed by the results of studies published by Weisz [12] who examined post-operative lesions after laminectomies performed using CT imaging tests. Deburge et al. assessed the use of FFT in patients treated for spinal canal stenosis less optimistically. Computed tomography scans revealed that the introduced fat tissue flap was thinner, its dimensions changed, and partial or even complete atrophy was observed [13]. Postoperative FFT monitoring with CT scan does not provide, in our opinion, sufficient information regarding remodelling, fibrosis, or vascularity. Additionally, it was observed that a CT scan performed several months after a surgery for lumbar degenerative spine (in order to assess the paraspinal tissues) and a surgery site without FFT does not provide significant correlation with the patient's clinical condition [14]. In many cases a CT assessment of the scar and the role of a fat tissue flap was performed based on the so-called laminectomy membrane. This term based on CT scans was introduced by La Rocca and Macnab in 1974, and they suggested that scar formation is a result of fibroblast invasion from the side of the musculus erector spinae [15]. In the 1980s, articles revealing abnormalities in imaging test findings following the use of fat autologous flap were published. There were cases of hypertrophic scar formation at the place where the dural sac had been covered by fat. Due to increased scar formation above the dural sac and in the surrounding tissues (visible in a radiological assessment) and accompanying clinical symptoms in many cases decisions were made to perform subsequent decompressing surgeries and to remove the fat graft along with a scar. FFT removed during a reoperation was examined histologically, and connective tissue fibrosis was observed $[12,16,17]$. In the 1980 s CT scans were the basis for such assessments, and they showed that fat changed its volume, and moreover it could change its density and vascularity. Collection of FFT fragments for a histopathological examination during a reoperation was especially valuable because it was possible to perform a histopathological assessment. Studies were based on tissue staining tests with eosin and haematoxylin. However, as a result it was more difficult to perform fat remodelling because alcohol-based solutions were used for staining. Publications by Kanamori et al. $[18,19]$ significantly affected the expansion of knowledge on the efficiency of FFT in the prevention of scar formation in lumbar disc surgeries. A histopathological assessment of FFT fragments collected during a reoperation due to progression of neurological symptoms demonstrated graft survival, an increased amount of collagen fibres, and proliferation of blood vessels. Morphological elements of the fat tissue were subject to reduction, polymorphism, and vacuolar degeneration; no signs of necrosis were observed $[12,16,17]$. Based on the fat graft survival [19] it was not justifiable to search for similarities with fat tissue that is anatomically present in the epidural space and its characteristics. Due to a high amount of collagen in the studied tissue and proliferation of blood vessels it is difficult to discuss anti-scar or anti-adhesive potential. It should be remembered that the idea of implementation of FFT assumed that a graft and natural fat tissue in the epidural space have the same morphological traits. Nevertheless, it was excluded in histopathological assessment. Similarities between the FFT signal and the signal of normal subcutaneous fat tissue were only revealed in MRI examination performed after a 1-year postoperative period [19]. Fat tissue imaging based on MRI studies confirmed approximately $50 \%$ of graft flap reduction, but the same examination performed 1 year later did not reveal FFT changes in $25 \%$ of the study group. An MRI examination in the early postoperative period showed blurred graft outlines, local tissue oedema, and compression of the meningeal sac. Along with regressing oedema and early fat tissue atrophy, the meningeal sac increased its dimension at the decompression site after approximately 6 weeks. This phenomenon was named as meningeal sac re-expansion [19]. The authors of this report, based on the experience of plastic surgeons, indicate the significance of fat graft preparation, homogeneity, and thickness, as it improves the conditions of local FFT survival. A very thin flap becomes ineffective due to postoperative atrophy observed in the early period of 6 weeks and later. According to the literature in the field of plastic surgery regarding the use of fat tissue graft as a filling agent, it is described as a highly absorptive material [20-25]. Based on many-year experience it was possible to determine the optimum width and a method of collection of a fat flap. In spinal surgery the FFT graft is usually collected from the hypodermis at the site of a surgical approach. Plastic surgeons recommend using fat graft from the buttock area due to better quality and a lower number of fibrotic elements [20-25]. A solid FFT fragment that has a better chance of survival is recommended over other techniques associated with fragmentation or dispersal [19]. However, additional incisions of the skin in minimally invasive procedures (MISS) affect the cosmesis. Usage of solid large FFT graft is recommended only in wide decompressive spinal surgery procedures above the dural sac. It may be associated with potential compression of neurological structures, i.e. cauda equina and spinal cord. To verify FFT applicability in the prevention of scar formation in a reliable way a long-term assessment of clinical courses and recovery must be made $[18,19,26,27]$. In the paper by Bernsmann et al. a group of patients treated with FFT was compared for the first time with a group without a fat tissue graft [28]. A post-treatment clinical assessment regarding a neurological condition and social activity was per- 
formed 24 months after the surgery. For the first time there were no statistically significant differences between the studied groups in postoperative course [28]. Other reports published later emphasise a lack of significant differences indicating lack of efficacy and applicability of FFT in the prevention of scar formation in degenerative spine surgery [29, 30]. There are opinions that FFT reduces scar formation, but without an influence on clinical improvement [31-33]. It is also true that a scar is formed from the inside of the spinal canal [34] and not from musculus erector spine, and the term "laminectomy membrane" in imaging examination received a more historical meaning. Autogenous fat tissue was assessed to be the least susceptible to scar formation compared to other autogenous materials, i.e. muscles, fascia, or gelfoam. Fat tissue morphology is well-known, but unfortunately it does not provide a solution to eliminate scar formation. The fat tissue is perceived as a reservoir of precursors of various types of cells. In biotechnological processes FFT is a source of stem cells (adipose-derived stem cells - ADSCs); therefore, it contains multipotent cells. At the department histological examinations performed after reoperations demonstrated vascular hyperplasia, which might have been associated with local induction of angiogenesis [19]. Those observations led to search for heterogeneous materials i.e. anti-adhesive, isolating and scar preventive, but unfortunately all of them are associated with a foreign-body reaction [35, 36]; this is the effect of ADSC precursors present in the fat tissue $[37,38]$.

Cauda equina syndrome is the most commonly observed neurological complication in lumbar spine surgery [39-46]. Reports indicated different mechanisms responsible for the compression, e.g. a haematoma formed between the dura mater and a fat fragment, mechanical compression as a result of the FFT graft being introduced, oedema of the surrounding tissues, or FFT hypertrophy in a later period demonstrated in diagnostics years after a surgery.

The symptoms appearing many years after surgery can be compared to cases of symptomatic fat collection - epidural lipomatosis that accompanies e.g. chronic steroid therapy and is reported in the literature [47, 48]. However, the most common finding in MRI examination is graft atrophy. In the literature there are no reports on the use of FFT to prevent the formation of a surgical scar in thoracosurgery and surgery of the cervical spine, probably for fear of a mass effect. In all symptomatic cases when there is a larger amount of the fat tissue in the spina canal it can correspond with lipomatosis.

FFT graft is additionally used with autogenous fascia lata to seal the dural sac liquorrhoea $[9,49,50]$. This procedure was introduced by Mayfield [9], who recommended to suture a fat flap at the site of the damaged dural sac. Compression and cauda equina syndrome may also be a result of FFT migration due to lack of appropriate attachment or suturing to the dural sac. The more dangerous effect of compression on the medulla could be observed when the fat graft was introduced above the dural sac using an anterior approach in the cervical spine to seal liquorrhoea [51].

\section{Summary}

Fat tissue in the form of FFT is an easily available autogenous material that is devoid of risks of a foreign-body reaction. Due to lack of possibility to monitor FFT for many years, there was an opinion that this material is of universal nature. At the beginning it was widely believed that the fat tissue had beneficial effects and it prevented from the formation of local scar tissue. Surgeons who observed atrophy and fibrosis during the procedures they performed presented a critical position regarding FFT. Suspecting that the fat tissue becomes transformed and atrophied, the use of FFT as effective prophylaxis in the spinal surgery was disputed. Unfortunately, because it was not possible to monitor FFT morphology at the site of use, there were no additional arguments in this essential discussion. Works regarding monitoring of FFT morphology using picture examinations $[8,11,12,14,18$, $19,26,27,31,51]$ with clinical reports regarding large groups of patients provided information that the use of FFT graft does not significantly affect therapeutic effects [28-31]. Introduced autogenous material becomes so extensively remodelled that it loses its initial properties of fat tissue. The use of FFT graft does not eliminate the phenomenon of local adhesion and scar formation between the region of the root or the meningeal sac due to a histopathologically confirmed mechanism of fibrosis. The solution to the problem of isolation in spine procedures and prevention of scar formation can probably be obtained with materials manufactured via nanotechnology [35]. Due to their special properties and the lack of a foreign-body reaction these materials can be used to form mobile isolation layers between anatomical structures without mass effect, adhesion, or scar tissue formation.

\section{Conflict of interest}

The authors declare no conflict of interest.

\section{References}

1. Lexer E. Die freien transplantationen. In: Neue deutsche Chirurgie 26 Stuttgart: Ferdinand Enke 1919; 264-545.

2. Hilse A. Experimentelle untersuchungen über freie fetttransplantation bei blutungen parenchymatöse bauchorgane. Langenbecks Arch Klin Chir 1914; 103: 1042-1083.

3. Rehn E. Die fetttransplantation. Langenbecks Arch Klin Chir 1912; 98: 1-37.

4. Thompson N. The subcutaneous dermis graft: a clinical and histological study in man. Plast Reconstr Surg 1960; 26: $1-22$. 
5. Figi FA. Depression of frontal region, fat transplant. Surg Clin North Am 1931; 11: 8-31.

6. Kiviluoto O. Use of free fat transplants to prevent epidural scar formation. An experimental study. Acta Orthop Scand Suppl 1976; 164: 3-75.

7. Langenskiöld A, Kiviluoto O. Prevention of epidural scar formation after operations on the lumbar spine by means of free fat transplants. A preliminary report. Clin Orthop Relat Res 1976; 115: 92-95.

8. Langenskiöld A, Valle M. Epidurally placed free fat grafts visualized by CT scanning 15-18 years after discectomy. Spine 1985; 10: 97-98.

9. Mayfield FH. Autologous fat transplants for the protection and repair of the spinal dura. Clin Neurosurg 1980; 27: 349-361.

10. Bryant MS, Bremer AM, Nguyen TQ. Autogeneic fat transplants in the epidural space in routine lumbar spine surgery. Neurosurgery 1983; 13: 367-370.

11. Van Akkerveeken PF, Van de Kraan W, Muller JW. The fate of the free fat graft. A prospective clinical study using CT scanning. Spine 1986; 11: 501-504

12. Weisz GM. The value of $\mathrm{CT}$ in diagnosing postoperative lumbar conditions. Spine 1986; 11: 164-166.

13. Deburge A, Benoist M, Lassale B, Blamoutier A. The fate of fat grafts used in surgery of the lumbar spine. Rev Chir Orthop Reparatrice Appar Mot 1988; 74: 238-242.

14. Jensen TT, Overgaard S, Thomsen NO, Kramp S, Petersen OF, Hansen JH. Postoperative computed tomography three months after lumbar disc surgery. A prospective single-blind study. Spine 1991; 16: 620-622.

15. La Rocca H, Macnab I. The laminectomy membrane. Studies on its evolution, characteristics, effects and prophylaxis in dogs. J Bone Joint Surg 1974; 56: 545-550.

16. Martin-Ferrer S. Failure of autologous fat grafts to prevent postoperative epidural fibrosis in surgery of the lumbar spine. Neurosurgery 1989; 24: 718-721.

17. Saunders MC, Keller JT, Dunsker SB, Mayfield FH. Survival of autologous fat grafts in humans and in mice. Connect Tissue Res 1981; 8: 85-91.

18. Kanamori M, Kawaguchi Y, Ohmori K, Kimura T, Md HT, Matsui $\mathrm{H}$. The fate of autogenous free-fat grafts after posterior lumbar surgery: part 1. A postoperative serial magnetic resonance imaging study. Spine 2001; 26: 22582263.

19. Kanamori M, Kawaguchi Y, Ohmori K, Kimura T, Tsuji H, Matsui $\mathrm{H}$. The fate of autogenous free-fat grafts after posterior lumbar surgery: part 2. Magnetic resonance imaging and histologic studies in repeated surgery cases. Spine 2001; 26: 2264-2270.

20. Coleman SR. Hand rejuvenation with structural fat grafting. Plast Reconstr Surg 2002; 110: 1731-1745.

21. Coleman SR. Long-term survival of fat transplants:controlled demonstrations. Aesthet Plast Surg 1995; 19: 421.

22. Omranifard M, Dahmardei M, Afshar Moghaddam N, Ansari M, Jazebi N, Otroj Z, Koushki AM. Comparison between five methods of fat grafting. J Res Med Sci 2012; 17: S108-S112.

23. Shiffman MA, Mirrafati S. Fat transfer techniques: the effect of harvest and transfer methods on adipocyte viability and review of the literature. Dermatol Surg 2001; 27: 819-826.

24. Markey AC, Glogau RG. Autologous fat grafting: comparison of techniques. Dermatol Surg 2000; 26: 1135-1139.
25. Scala J, Vojvodic A, Vojvodic P, Vlaskovic-Jovicevic T, PericHajzler Z, Matovic D, Dimitrijevic S, Vojvodic J, Sijan G, Stepic N, Wollina U, Tirant M, Van Thuong N, Fioranelli M, Lotti T. Autologous fat graft: not only an aesthetic solution. Open Access Maced J Med Sci 2019; 7: 2961-2963.

26. Montaldi S, Fankhauser H, Schnyder P, de Tribolet N. Computed tomography of the postoperative intervertebral disc and lumbar spinal canal: investigation of twenty-five patients after successful operation for lumbar disc herniation. Neurosurgery 1988; 22: 1014-1022.

27. Tullberg T, Rydberg J, Isacsson J. Radiographic changes after lumbar discectomy. Sequential enhanced computed tomography in relation to clinical observations. Spine 1993; 18: 843-850.

28. Bernsmann K, Krämer J, Ziozios I, Wiese M. Lumbar micro disc surgery with and without autologous fat graft. A prospective randomized trial evaluated with reference to clinical and social factors. Arch Orthop Trauma Surg 2001; 121: 476-480.

29. Dobran M, Brancorsini D, Della Costanza M, Liverotti V, Mancini F, Nasi D, Iacoangeli M, Scerrati M. Epidural scarring after lumbar disc surgery: equivalent scarring with/ without free autologous fat grafts. Surg Neurol Int 2017; 8: 169 .

30. Görgülü A, Simsek O, Çobanoglu S, Imer M, Parsak T. The effect of epidural free fat graft on the outcome of lumbar disc surgery. Neurosurg Rev 2004; 27: 181-184.

31. Jensen TT, Asmussen K, Berg-Hansen EM, Lauritsen B, Manniche C, Vinterberg H, Jensen L, Kramhøft J. Firsttime operation for lumbar disc herniation with or without free fat transplantation. Prospective triple-blind randomized study with reference to clinical factors and enhanced computed tomographic scan 1 year after operation. Spine 1996; 21: 1072-1076.

32. Feng MX, Hong D. Update on prevention of epidural adhesion after lumbar laminectomy. China J Orthoped Traumatol 2015; 28: 1064-1068.

33. Chin KR, Bassora R, Yu WD. Safety and usefulness of free fat grafts after microdiscectomy using an access cannula: a prospective pilot study and literature review. Am J Orthop 2014; 43: 66-69.

34. Abitbol JJ, Lincoln TL, Lind BI, Amiel D, Akeson WH, Garfin SR. Preventing postlaminectomy adhesion. A new experimental model. Spine 1994; 19: 1809-1814.

35. Andrychowski J, Frontczak-Baniewicz M, Sulejczak D, Kowalczyk T, Chmielewski T, Czernicki Z, Kowalewski TA. Nanofiber nets in prevention of cicatrisation in spinal procedures. Experimental study. Folia Neuropathol 2013; 51: 147-157.

36. Andrychowski J, Czernicki Z, Taraszewska A, FrontczakBaniewicz M, Przytuła E, Zębala M. Granulomatous inflammation of dura mater: a rare side effect after application of hemostatic and insulation materials in case of two-stage operation of huge meningioma. Folia Neuropathol 2012; 50: 417-424.

37. Lendeckel S, Jödicke A, Christophis P, Heidinger K, Wolff J, Fraser JK, Hedrick MH, Berthold L, Howaldt HP. Autologous stem cells (adipose) and fibrin glue used to treat widespread traumatic calvarial defects: case report. J Craniomaxillofac Surg 2004; 32: 370-373.

38. Abudusaimi A, Aihemaitijiang Y, Wang YH, Cui L, Maimaitiming S, Abulikemu M. Adipose-derived stem cells enhance bone regeneration in vascular necrosis of the 
femoral head in the rabbit. J Int Med Res 2011; 39: 18521860.

39. Cobanoğlu S, Imer M, Özylmaz F, Memi M. Complication of epidural fat graft in lumbar spine disc surgery: case report. Surg Neurol 1995; 44: 479-482.

40. Strömqvist B, Jönsson B, Annertz M, Holtas S. Cauda equina syndrome caused by migrating fat graft after lumbar spinal decompression. A case report demonstrated with magnetic resonance imaging. Spine 1991; 16: 100-101.

41. Prusick VR, Lint DS, Bruder WJ. Cauda equina syndrome as a complication of free epidural fat-grafting. A report of two cases and a review of the literature. J Bone Joint Surg Am 1988; 70: 1256-1258.

42. Cabezudo JM, Lopez A, Bacci F. Symptomatic root compression by free fat transplant after hemilaminectomy. Case report. J Neurosurg 1985; 63: 633-635.

43. Mayer PJ, Jacobsen FS. Cauda equina syndrome after surgical treatment of lumbar spinal stenosis with application of free autogenous fat graft. A report of two cases. J Bone Joint Surg Am 1989; 71: 1090-1093.

44. Imran Y, Halim Y. Acute cauda equina syndrome secondary to free fat graft following spinal decompression. Singapore Med J 2005; 46: 25-27.

45. Urvoy P, Perlinski S, Berger M, Butin E, Mestdagh H. Cauda equina syndrome due to early postoperative migration of an adipose tissue flap following laminectomy. Acta Orthop Belg 1990; 56: 513-516.

46. Chuang TY, Chen WJ, Chen LH, Niu CC, Shih CH. Acute postoperative aggravation of radiculopathy as a complication of free fat transplantation in lumbar disc surgery: case report. Changgeng Yi Xue Za Zhi 1999; 22: 498-502.

47. Randall BC, Muraki AS, Osborn RE, Brown F. Epidural lipomatosis with lumbar radiculopathy: CT appearance. J Comput Assist Tomogr 1986; 10: 1039-1041.

48. Zampella EJ, Duvall ER, Sekar BC, Langford KH, Epstein AE, Kirklin JK, Morawetz RB. Symptomatic spinal epidural lipomatosis as a complication of steroid immunosuppression in cardiac transplant patients. Report of two cases. J Neurosurg 1987; 67: 760-764.

49. Kitchel SH, Eismont FJ, Green BA. Closed subarachnoid drainage for management of cerebrospinal fluid leakage after an operation on the spine. J Bone Joint Surg Am 1989; 71: 984-987.

50. Black P. Cerebrospinal fluid leaks following spinal surgery: use of fat grafts for prevention and repair. Technical note. J Neurosurg 2002; 96: 250-252.

51. Kansal R, Nama S, Mahore A, Dange N, Kukreja S. Fat graft migration causing recurrent cervical cord compression. Turk Neurosurg 2012; 22: 502-505.

\section{Address for correspondence:}

Jarosław Andrychowski MD, PhD, D.Sc., Ass. Prof.

Collegium Medicum

Jan Kochanowski University

Al. IX Wieków Kielc 19 a, 25-516 Kielce, Poland

Phone: +48 4134969 11, +48 501121757

Fax.: +48413496916

E-mail: j.andrychowski@wp.pl 